\title{
CULTURAL AMBITIONS OF CITIES IN CENTRAL AND EASTERN EUROPE IN THE LIGHT OF TWO CITIES' - TALLIN AND MARIBOR - CASE STUDIES
}

\section{KULTURÁLIS AMBÍCIÓK KELET-KÖZÉP-EURÓPA VÁROSAIBAN KÉT VÁROS - TALLIN ÉS MARIBOR - ESETTANULMÁNYÁNAK TÜKRÉBEN}

\author{
Szabolcs MORVAY \\ a Széchenyi István University, Faculty of Economics. Györ, Egyetem tér 1. H-9026; \\ morvay.szabolcs@sze.hu
}

Cite this article: Morvay, S. (2017). Cultural Ambitions of Cities in Central and Eastern Europe in the Light of Two Cities' - Tallin and Maribor - Case Studies. Deturope, 9(3):162-176.

\begin{abstract}
The cities of Central and Eastern Europe have recognized those trends, which are already visible in the Western Europe on cultural sphere. The Western European cities generate development of society and economy based on culture. These trends came up with the age of knowledge-based economy. The cultural economy and the creative economy are spreading more and more in the Western Europe. The progress is helped by the European Union through several cultural project. For example the European Capital of Culture program. Participation in this process has become a strategic weapon for cities seeking to attract cultural visitors. Nowadays, the event has certainly developed beyond its cultural origins. It is becoming a part of urban economic and cultural revitalization. Since 2007 Central and Eastern European cities also can be the title holder of the European Capital of Culture. The first city was Sibiu in Romania in Central and Eastern Europe. I examine the impacts of the European Capital of Culture program on the local economy and society in the cities in Central and Eastern Europe.
\end{abstract}

Keywords: culture, economic development, cities, Central and Eastern Europe, European Capital of Culture

\section{Kivonat}

Kelet-Közép-Európa nagyvárosai felismerték azokat a trendeket, amelyek Nyugat-Európában figyelhetőek meg a kulturális szférában. A nyugat-európai városok társadalmi és gazdasági fejlödést a kultúra bázisán építenek. A trendet egy új kor, a tudás alapú gazdaság kora hozta magával. A kulturális gazdaság és kreatív gazdaság egyre nagyobb mértékben bontakozik ki a nyugati országokban. A folyamatot segíti az Európai Unió kulturális politikája is különböző programokkal, projektekkel. Az egyik kiemelendő projekt az Európa Kulturális Fővárosa cím birtoklása. A projektben való részvétel szinte mármár stratégiai „,fegyverré” vált a városok kezében abból a célból kifolyólag, hogy látogatókat vonzanak kulturális attrakciókkal. Manapság, az esemény túlmutat a kulturális értékén. Része a városok gazdasági és kulturális megújulásának. 2007 óta kelet-közép-európai városok is pályázhatnak a címre. Az első e térségbeli város Nagyszeben volt. A tanulmányban a cím birtoklásából fakadó kulturális boom hatásait vizsgáljuk gazdasági és társadalmi vonatkozásban a kelet-közép-európai nagyvárosok esetében.

Kulcsszavak: kultúra, gazdasági fejlődés, városok, Kelet-Közép-Európa, Európa Kulturális Fővárosa 


\section{INTRODUCTION}

The course of history economic development has brought changes of employment structure. This development can be divided into three phases: the pre-industrial, industrial and postindustrial. The division is at tributed to Daniel Bell, an American sociologist, who is the famous researcher of the post-industrial era, their works are classic on the topics. The process of development marginalized the dominance of agricultural sector, initially created the expansion of the industry, and later the service. So the post-industrial stage is the age of service society, such as Bell explains. (Bell, 2001)

The post-industrial era or post-industrial society emerged in the Western societies. This social transformation can be explained not only with changing technology, but primarily with the change of consumer behavior. The consumer society brought the expansion of the cultural sphere. Likewise the demand for cultural goods has also increased. The global processes have replaced the Fordist mass production with the post-Fordist economy. The investment on material capital, the raw material-based economy contribute not fully to the competitiveness of countries, research and development, innovation, creativity, appreciation of human capital are the driving force of development. We observe the rapid emergence of new trends in the western developed countries - increasing rate of growth of the creative economy and cultural economy. Mainly Western European and North American regions tended to counteract the degraded industrial sectors by cultural investment and establishment of research institutions. It can be mentioned Birmingham educational and cultural complexes, Pittsburgh's cultural institutions, or the Ruhr region as an example. (Enyedi, 2005; Florida, 2002)

In addition transformation can be observed in the government policy, because began to prevail active public service, promoting local development policies instead of passive enforcement of state policy. The development of so-called creative cities has become a part of a strategy by which they were able to attract investors and highly educated, highly qualified professionals who Richard Florida calls the creative class. This strategy included the implementation of an elitist policy which favored, facilitated the so-called gentrification. In this strategy, it started the revitalization of cities, on a broad base of architectural projects and cultural institutions. (Bianchini, 1993)

Spectacular events began to enrich the cultural life of the cities and started build-up the creative and cultural-industrial clusters. The process brought the creation of modern infrastructure. Dynamic local milieu facilitated the unfolding of a wide range of entertainment options, restaurants and night life. (Rius-Ulldemolins, 2014) 
The cultural strategies focused initially on cultural tourism and boosting of consumption, and the cities tried to improve the city's image, the picture of city by creating large, iconic cultural project, art districts and places of entertainment. In the 1990's increasingly recognized the role of human capital and innovation in the urban growth, at the same time the political discourses turned toward the art and media activities, which were traditionally separate spheres. (Flew, 2012)

The cities of Central and Eastern Europe have recognized these trends, which are already visible in the Western Europe on cultural sphere. The Western European cities generate development of society and economy based on culture. These trends came up with the age of knowledge-based economy. The cultural economy and the creative economy are spreading more and more in the Western Europe. The progress is helped by the European Union through several cultural project. For example the European Capital of Culture program. Participation in this process has become a strategic weapon for cities seeking to attract cultural visitors. Nowadays, the event has certainly developed beyond its cultural origins. It is becoming a part of urban economic and cultural revitalization. Since 2007 Central and Eastern European cities also can be the title holder of the European Capital of Culture. The first city was Sibiu in Romania in Central and Eastern Europe.

I examine the impacts of the European Capital of Culture program on the local economy and society in two cities in Central and Eastern Europe. This cities are Tallinn and Maribor, because I deal former with Pécs (a city in Hungary), which city was European Capital of Culture in 2010, and in the following years, in 2011 and 2012 Tallinn and Maribor were the title holders. Thus these two cities I examine in with respect to project, economic and social impacts of the ECC title. I highlight the goals of the cities, which they want to reach by culture, and I describe the achieved results.

\section{THE CONCEPT OF CULTURE}

The concept of culture is important in this study, because the study examine the impacts of certain cultural programs, that is we must understand what is culture, what include the cultural programs, how to characterized the subject of these programs? Why special the impacts of cultural projects?

The term is derived from the Latin 'colere' word, which is related to the agriculture, the expression means cultivation, nursing and care, thus actually word meant cultivation of the land. Presumably, also the human spirit wishes cultivation, thus makes sense the use of the 
original expression to "polishing" of the human mind and thoughts. This brings us to the Latin "culture" that encompasses the cultivation of intellectual and artistic activity and the artworks, which derived from this kind of activity. (Williams, 2003)

However, the concept of culture is much wider; literatures on the subject accept a broader interpretation of the topic. This means that not only examine the content of high culture - as I have defined the term "culture" above - but also the concept sets out in its meaning accumulated knowledge, value systems, models of behavior, habits and beliefs. (Kroeber, 1997)

A number of disciplines addressed with the concept of culture, a result of which many concepts were born. Kroeber and Kluckhohn counted 165 definitions, which they collected their own work: Culture. A Critical Review of the Concepts and Definitions. (Kroeber \& Kluckhohn, 1952)

However, can be managed the abundance of definitions with designation of two lines. The first interpretation represents the anthropological approaches, the second one represents the normative approaches. Anthropology ascribes culture to human specificities. However, the normative interpretation understands below culture the products of human's creative activities. At the same time the narrow interpretation of the culture exists, which means high value intellectual performance, such as art, literature, philosophy, science. And the broad interpretation of culture is such cultural communication, which is found in many spheres of society. (Ács, 2008)

Unified concept - which is accepted by all researchers, who deal with the subject - did not develop. Basically, the content of the phenomenon of culture is highly complex. And definitional issues are difficult due to the fact that different disciplines approach the topic under different respects. (Hrbácsek-Noszek, 2011)

In case of regional science analyses and economic analysis we cannot interpret the concept as a comprehensive content. Because, different cultural contents influence the spaces and using of spaces in different ways. Actually, the type of cultural manifestation is in the focus, when the approach is the spatiality. So in this case we understand under culture the cultural activities, such as music, painting, sculpture, gallery, museum, etc. In the following parts of paper we examine that this activities how to contribute to the economy of a city.

\section{THE ANALYSIS OF THE ECONOMIC IMPACT OF CULTURE}

It is important to dealing with the economic impact of culture. As the ECC project's expected impact should be to the economy of the city. There are requirements that the ECC programs 
have long-term (positive) consequence to the economy. Whether there are at all any impacts of the cultural activities to the economy of a region or city?

According to traditional approach - culture is costly - cultural activities have a negative impact on the economy, we must this state so understand that it not produce profit. Basically lack of equilibrium between supply and demand causes anomalies - that is the supply exceeds the demand of culture. This is because of the fact the cultural activity has proven to be deficient. That is to say that the deficit of the budget of the cultural activities is typical. To the market balance contribute the government support. The view does not enjoy great popularity and many economists (for example Richard Florida) say that culture creates large numbers of jobs and major income. There is also a statement that culture is one of the variety industries and it has neutral impact on the economy. The culture economy can be expanded to creative industry and the result is a wider set. It must be separated from direct, indirect and spillover impacts if you want to get a full picture of the economic impact of culture. (McCarthy, 2004)

In Hofstede's early work (Hofstede, 1980), among the cultural values, individualism, or compassion, power distance, and morality have become one of the variables, one of which is positively influenced by one of the variables on economic growth. A 1991 research (Franke, Hofstede, \& Bond, 1991) states that cultural differences (as independent variables) affect the economic growth of countries. They took into account the impact of political culture on growth (Jackman \& Miller, 1996), which is the conclusion that the relationship between political culture and growth is negligible. Political culture is based on elements - without the need for completeness - as authors, as the support of the existing order, the level of political dialogue, the support of revolutionary changes, or the trust between people. Cultural elements have also been captured and analyzed, such as performance motivation and postmaterial values. With their authors in Granato, in 1996, the two variables have a significant influence on economic growth and emphasize that economic and cultural factors stimulate growth together. Edwards and Patterson make this exactly the opposite in their 2009 study. (Kapás, 2016)

In addition the historical determinism can be incorporated into the analysis. Because the post-industrial society brings the changes of employment structure, as a result of this nowadays the heavy industrial sectors create fewer jobs than the various branches of creative industry, such as the audiovisual sector. Let's examine the indirect impacts. We can consider that the spread of creative sectors can give new ideas and technologies to other sectors. 
Culture presents these new ideas in the economy, because the artistic sector an integral part of the economy, an innovative system for the entire economy. (Greffe, 2016)

It can be said that the art's activities are also an attraction in the tourism sector, such as cultural activities and tourism generate mutually beneficial impacts. The more and more expanding consumption and entertainment possibility become increasingly available for tourists. It means that the supply become clearer by the development of info-communication technology, information will be available to the demand, in addition the development of transportation infrastructure contributes to overcoming physical barriers. Reciprocity is also reflected that the growth of the tourism industry strengthens the financial viability of cultural activities and it increases the possibility of patronage as well. (Torre \& Scarborough, 2017)

The tourism is an advancing sector in Europe considering the growth rate of this sector. As direct economic impact we can mention the creation of many new jobs in the sector. The attractiveness of the region influence the number of tourists, visitors and this is influenced by the value and quantitative and qualitative criteria of tourist attraction as well as their presentation ability. The tourism is an important source of revenue for the regions and it has a major role as regards the employment in many other regions in Europe. In addition, competitive factors as well. The European Union attributed to legitimate importance to the sector, which contributes to sustainable social and economic goals. However, the sector was faced with many challenges by the global economic crisis and the increased competition with other sectors and the consequences of climate change can be mentioned as well. The culture come up here by it, that we interpret the tourism industry in the context of culture, that is the culture is actually the object of tourism. That is the role of culture tourism will be discussed. One the highlighted cultural element is the cultural heritage in this discussed aspect. If a region has a unique cultural value, it can appear in the tourism market, this can contribute to employment growth. A region or some city can form its identity, character, image by their cultural heritage. (Petronella, 2016)

Cultural values of the region can be interpreted as a form of territorial capital as a source of development. This is experience not only for tourists but also for local people, generating social, economic and environmental impacts. The economic value measured by the gross added value and it has multiplier impact in the economy, tourists visit and consumption in the region bring income from other regions. (Mateja, David, \& Primoz, 2015)

The spill-over impacts of the arts to economy can be classified into four pillars. The primary impacts should search in direct commercial value. Secondly the spending on the arts will generate multiplier impacts. Thirdly the arts contribute to birth of industrial idea and 
innovation and the fourth can be mentioned as an effective contribution to quality of life, identity and plurality. (Heng, 2003)

\section{CULTURE IS TERRITORIAL CAPITAL}

Culture can be exploited as a territorial capital of a city or region if it has unique or highquality cultural values. But, what is territorial capital?

Pierre Bourdieu extended the capital concept of economics, he takes stock all its manifestations, which are the following. The capital appears as accumulated labor, which form may be material or embodied. Depending on the area in which function and in concern of transformation costs the capital may be three manifestations. Economic capital, which immediately and directly convertible into cash and can be institutionalize in the form of property rights. The second aspect is the cultural capital, which is converted into economic capital under certain conditions and can be and institutionalize in the form of education. Finally there is social capital which constitutes social obligations and relationships. It transforms to the economic capital, under certain conditions, or may institutionalize, for example in the form of noble titles, ranks, titles. According to Bourdieu cultural capital can also take three forms. The first form: in the embodied state it is interpreted as a long-term disposition of spirit and body. The second form: the objectified form of the culture appears as cultural goods, such as paintings, books, tools. The third form: the institutionalized form of cultural capital that is legally recognized by titles. (Bourdieu, 1986)

Bourdieu is the major researcher of the subject. But among the statement of Bourdieu we must deal with further statement, which connect to the cultural context. In the concept of territorial capital we can be found the intangible capital stock. The inta ngible assets of a nation can describe by such elements as knowledge, level of culture, traditions, national morale. The competitiveness of the country is more and more determined by their invisible, specific, unique, intangible values, which are increasingly important for foreign investors. Investment in research, development, innovation is the most important source of development of cities, and this investment contributes to growth of knowledge capital and intellectual capital. All these are conditions of value creation, even if we talk about corporate or regional aspect. European Union countries and regions try to implement the national and regional innovation strategies, to achieve the Lisbon objectives, which intend to raise Europe's economy to the most competitive knowledge-based economy. (Rusu-Tanasa, 2015) 
Florida's theory of the economic success of cities and regions includes the activating of internal resources of cities and regions. As a result of activation of internal resources, the development of the city may bring new developmental elements such as inflows of creative workers into area. According to Florida this latter process depends on the city what extend developed in such factors, as technology, talent management, tolerance to attitudes of creative people. (Florida, 2002) Investigations which were adapted for Europe with regard to the above show to the Scandinavian countries are in the lead and the Western European countries. Countries of Central and Eastern Europe are only in the second ten groups. (Ságvári, \& Dessewffy, 2006)

\section{EUROPEAN CAPITALS OF CULTURE}

The research question the role of culture in the regional development. The European Capitals of Culture program contributes to the regional development by the cultural programs. In the former parts of this paper I show the impacts of culture theoretic way. Now, let see the practical way.

One of the key themes of cultural programs of the European Union is the European Capital of Culture. The title awarded to some city of the European Union for a period of one year, which included the presentation of the city's cultural life and cultural developments. In 1985, when the European Community Culture Ministers accepted the invitation of the Greek minister of culture to Athens, born the idea that culture receives the same importance in the European Community, as the economy or trade. Namely there is economic policy, there is trade policy, let be cultural policy of the European Union. The European Capital of Culture event provides an opportunity for European cities to show their cultural program for one year, which highlight the richness of European culture, diversity and commonalities. (Csekö, Mesterházy, \& Zongor, 2004)

The program started in 1985 with Athens and since then the organizers choose Europe's cultural capital every year. The period covers other processes that are related to culture, such as cultural heritage, appreciation of uniqueness. In the beginning the goal was none other than the variety of European culture to become well-known to all. In the following years more and more target added to the original idea. The program includes not only festivals, but also 
professional dialogues, forums and consultations and involvement of wider audience into debates of culture. ${ }^{40}$

The major cities of Central and Eastern European countries can be ECC-title holders since 2007, in which these cities can organize cultural programs. In 2007 Sibiu (Romania) was a Capital of Culture; in 2008 was not city in this macro-region Capital of Culture. In 2009, Vilnius (capital of Lithuania), chronological order Pécs, Tallinn (Estonia), Maribor (Slovenia), Kosice (Slovakia), Riga (Latvia), Plzen (Czech Republic), Wroclaw (Poland) were the title holders. ${ }^{41}$

\section{TALLINN AND MARIBOR}

Tallinn is the capital and largest city of Estonia. The number of its inhabitants can be over 400,000 , one third of which is a Russian ethnicity. Its territory is $159.2 \mathrm{~km} 2$ and in the northern part of Estonia is the coast of the Gulf of Finland. Tallinn is the most important and largest provider, commercial and financial center of the country. Highly developed information and communication technology infrastructure and IT sector in Tallinn. Tallinn is the driving force of Estonia, the development of which has a significant impact on other regions as well. ${ }^{42}$

Slovenia's second largest city after Ljubljana is Maribor, with about 119071 people. The development of the city is largely determined by its geographical position as it lies on one of the important urban development axes, which stretches from Kopert to Maribor. Rings around the two big cities in Slovenia include sixths of the country's settlements and $52 \%$ of its population. Maribor and its surroundings is the most urban area in the eastern part of the country. $^{43}$

In the following parts I examine these two cities in the context of ECC project, because I am seeking the benefit impacts of the cultural activities.

\section{TALLINN IS CULTURE CAPITAL OF EUROPE}

The Council of Ministers of the European Union designated the 2011 European Capital of Culture (ECC) holders by the decree of 2006, the cities of Estonia and Finland. In Estonia

\footnotetext{
${ }^{40}$ European Communities, 2009 European Capitals of Culture: the road to success from 1985 to 2010, Belgium

${ }^{41}$ www.uneecc.org

${ }^{42}$ Tallinn Annual Report 2011, Tallinn City Office

${ }^{43}$ Ex-post Evaluation of 2012 European Capitals of Culture, ECOTEC
} 
took place the national contest in two rounds. In the first round in 2005, were launched the following cities: Haapsalu, Pärnu, Rakvere, Tartu and Tallinn. In the second round there were only two cities competing, Tallinn finally won the title. ${ }^{44}$

The objectives or cultural ambitions of Tallinn we can read in its applications. The city formulates the following:

- Create such urban environment, that focuses further opportunities and development of creative activities and initiatives of the citizens.

- Provide resources for development of cultural infrastructure to meet the growing cultural needs of the citizens.

- Provide guidelines for the creative economy to be able to integrate into Tallinn's business community.

- Promote cultural communication between Estonia and other European nations art communities.

- Create new projects and collaborations in order to Tallinn to become an open, multicultural city and help existing and future community events with financial and development plans.

- Access to the city to become an important market in European dimension and an attractive place for tourists.

The question is whether the objectives have been achieved? We can see that there are economic aims and social aims, aims about development of tourism, infrastructure, creative economy, cultural communication. The ECC has failed to fulfill the original vision, but it still generated economic and urban development. Due to the reduced budget the infrastructure investment decreased. However, some specific developments can be highlighted. For example the seaside investment, which the cities today able to live better it's this aptness. Coastal areas have been chosen in new ways not only in the context of the European Capital of Culture, but then it was an important venue for the events. Developments in the area also took place in 2013 as well. The ECC is a specific way to shed light on this previously abandoned and neglected parts to imaginative reuse, exploit the inherent potential. Furthermore, it can highlight the cultural sector players have gained international relations, as well as have intensified cooperation between the various branches of the arts and other sectors. In connection with the social development it is important to note that managed to increase

${ }^{44}$ Report from the Commission to the European Parliament, the Council, the European Economic and Social Committee and the Committee of the Regions, Brussels, 2013 
participation in the culture for the inhabitants side. More results are that the former industrial areas managed to create a better state, thus these could serve as a location for cultural events. A series of programs during the year in these industrial spaces, 40,000 visitors visited here. The program includes 251 projects and more than 7,000 events. The whole event has attracted some two million visitors. 17\% increase in the number of foreign tourists in 2011 compared to 2010. $22 \%$ increased the number of overnight stays in the same period in Tallinn. $12 \%$ more domestic tourists traveled to Tallinn in $2011^{\text {th }} .45$

\section{MARIBOR IS CULTURE CAPITAL OF EUROPE}

Maribor was owned by European Capital of Culture title in 2012 together with four partner cities, which are: Murska Sobota, Novo Mesto, Ptuj, Slovenj Gradec and Velenje. The Government of Slovenia launched the submit applications process in 2006. Maribor built the application around the theme of "clean energy", this was the key concept, and referring to the role of region in the energy production and referring to that the "generated energy" spend on culture in 2012. The developmental stages were constant changes in management and staff. There was no agreement on the institutional form and financing and investment into infrastructure. Finally, in 2010, it founded the European Capital of Culture agency: Maribor 2012 Public Institution. This agency recruited the key people, and made new concept and slogan. The final program was presented to the public and the media in October 2011, so it had very little time to organize support activities (international promotion). ${ }^{46}$

In case of Maribor in application the following objectives have appeared ${ }^{47}$ :

- Integrated approach mean in the application, that the concepts such as creativity, heritage, education, research, digital literacy, cultural tourism, economy, ecology all together given the philosophy of "clean energy".

- Aim is the sustainable development in the region, creating new jobs, economic growth, increasing the region's competitiveness.

- Further aims are the creative use of modern information and communication technologies, exploitation of renewable energy sources.

- Building collaborations within the region and outside.

\footnotetext{
45 Tourism in Tallinn 2011; Tallinn City Tourist Office \& Convention Bureau, 2012; Ex-post evaluation of 2011 European Capitals of Culture, ECORYS, 2012

${ }^{46}$ Ex-post Evaluation of 2012 European Capitals of Culture

${ }^{47}$ MARIBOR 2012 - The European Capital of Culture
} 
- Enhancing the local identity and the access to culture for local residents, cooperation with politicians, building the information society.

- International awareness of Maribor, development of international cooperation, strengthen the cohesion of the eastern region of Slovenia.

- Cooperation with non-profit organizations and the commercial sector.

- Establish the conditions for creativity through the development of cultural infrastructure.

- The renovation of cultural heritage, the fostering of existing assets.

- Important to develop the tourism sector offerings by the expansion and development of transport and the opportunities of recreation.

- Digital culture should create new virtual contents.

- Stimulate dialogue between different cultures, ethnic minorities, and religious communities.

- Develop educational programs.

- Integrate all social groups, especially the most vulnerable (the elderly, the homeless, the unemployed, young people, people with disabilities).

In the application was originally great importance the impacts of ECC project to possibilities of development of city, ability which result social and economic development. However, did not succeed a number of investments to implement, but nevertheless managed to incorporate elements of urban development into content of program, any core objectives, which are achieved by the culture, can take success. Among others managed to give to the city a new impulse, they were able to build deeper trust among the local population and new connections have been established, all these result social and economic development. The demand increased for culture by the local population. The city center managed to revive. The circulation of the whole city started, since the cultural heritage projects were several place in the city. Most direct economic impact that the supply of tourism sector developed. The main element of the strategy that the city havs built is cooperation with the Slovenian Tourist Board and local governments, as well as trade partners such as bus operators, tourist offices. New information points have been established in Maribor and Ljubljana. Due to the ECC identified a number of activities, which are based on the relationships between culture, creativity and other areas. For example, the Maribor University conducts researches with other university faculties. In Eastern Slovenia happened noticeable economic and cultural growth by the program series. 3.8 million people were participating in cultural events, which is tourism 
boom. In 2012 more than 700 thousand nights spent in the city 900 thousand foreign visitors. Estimated profit was 1 million euro as a result of marketing. 600 new jobs have been created the end of the project. The organizers have implemented 405 projects, of which 308 at Maribor, 97 created the partner cities and 38 public / networking project. The projects contained 5624 events themselves, in which in 20123.1 million people took part, including a couple of years prior to 2012 as well 4, 5 million people visited the events. ${ }^{48}$

\section{CONCLUSION}

The cities of Central and Eastern Europe have recognized those trends, which are already visible in the Western Europe on cultural sphere. The Western European cities generate development of society and economy based on culture. These trends came up with the age of knowledge-based economy. The idea spread to cities of CEE. The progress is helped by the European Union through several cultural projects. For example the European Capital of Culture program. Participation in this process has become a strategic element for cities seeking to attract cultural visitors. Since 2007 Central and Eastern European cities also can be the title holder of the European Capital of Culture. After Pécs title holders were Tallinn and Maribor, in 2011 and in 2012. The cities formulated their ambitions, that is, what wish to reach by culture. I examined, what managed to reach of these objectives. The impacts realized mostly in the tourism sector. We can said, that happened tourism boom in the years of the project. In addition there were social impacts also, for example managed to increase participation in the culture for the inhabitants side and managed to give to the cities a new impulse by the culture. In these cities the cultural programs included several specific events, which were all built on international cooperation.

During these events counless extra ordinary and excellent artist and performers did their extra mile for the sake of arts.

Therefore Mariborer and Talliner artworld established the future fundamentals of the internetional social network and reputation.

Along the realization of the project a management has been formed, which gathered sufficient amount of experience about the local cultural sphere and the city council have got a better insight of the regional cultural life.

\footnotetext{
${ }^{48}$ Ex-post Evaluation of 2012 European Capitals of Culture, ECOTEC
} 
Both the privat asset and individuels sponzors performed weakly in the finance of ECC project. Based on my experience all the maecenas were absent, so we should find a way to lure in them in the future, it is not the most visual method yet.

Infrastructure investment have revealed new spaces in the city, gave new impulses to the city. The number of visitors was generally 1.4-2 million persons. This is tourism boom.

\section{REFERENCES}

A Bizottság jelentése az Európai Parlamentnek, a Tanácsnak, az Európai Gazdasági és Szociális Bizottságnak és a Régiók Bizottságának, A 2011-es Európa Kulturális Fővárosa (Tallinn és Turku) eseménysorozat utólagos értékelése. Brüsszel, 2013

Ács, M (2008). A kultúra helye és szerepe az Európai Unió regionális politikájában. In: Pap Norbert (szerk.): Kultúra - Területfejlesztés Pécs - Európa Kulturális Fővárosa 2010ben, Imedias Kiadó, pp.: 15-35. Pécs

Bell, D. (2001). Az információs társadalom társas keretrendszere. Elektronikus Periodika Archivum, 1(1), 1-31.

Bianchini, F. (1993). Urban Cultural Policy in Britain and Europe: Towards Cultural Planning. pp. 214.

Bourdieu, P. (1986). „The Forms of Capital”. In: Imre Szeman - Timothy Kaposy (szerk.) (2011). Cultural Theory An Anthology. Wiley-Blackwell, A John Wiley \& Sons, Ltd., Publication. United Kingdom

Csekő, S., Mesterházy, B., \& Zongor, A. (2004). Európa Kulturális Fővárosa, Kultúrpont

Enyedi, Gy. (2005). A városok kulturális gazdasága. In: Enyedi Gy., \& Keresztély K. (szerk.): A magyar városok kulturális gazdasága. MTA TKK, Budapest, pp. 13-31.

European Communities, 2009 European Capitals of Culture: the road to success from 1985 to 2010, Belgium

Ex-post evaluation of 2011 European Capitals of Culture, ECORYS, 2012

Ex-post Evaluation of 2012 European Capitals of Culture, ECOTEC

Flew, T. (2012). The creative industries: Culture and policy. London: Sage Publications.

Florida, R. (2002). The Rise of the Creative Class. New York: Basic Books.

Franke, R. H., Hofstede, G., \& Bond, M. H. (1991): Cultural Roots of Economic Performance: A Research Note. Strategic Management Journal, 12, Special issue: 165173

Greffe, X. (2016). From culture to creativity and the creative economy: A new agenda for cultural economics. City, Culture and Society 7. pp.: 71-74.

Heng, T. M., Choo, A., \& Ho, T. (2003). Economic Contribution of Singapore's Creative Industries, Economic Survey of Singapore First Quarter.

Hofstede, G. (1980): Culture's Consequences: International Differences in Work-Related Values. Beverly Hills, CA: Sage Publictions

Hrbácsek-Noszek Magdaléna (2011). Regionális tudat az iskolában. Ab-Art, Pozsony

Jackman, R. W., \& Miller, R. A. (1996). A Rennaissance of Political Culture? American Journal of Political Science, Vol. 40, No. 3: 623-659.

Kapás, J. (2016). A kultúra szerepe a gazdasági növekedésben: összefoglalás, kritika és továbblépési utak. Competitio XV. évf., 2. szám, 22-44. o.

Kroeber, A. L. (1997 ). A kultúra fogalma a tudományokban. In: Bohannan P. é Glazer, M. (szerk.): Mérföldkövek a kulturális antropológiában. Panem Kft., Budapest 
Kroeber, A. L., \& Kuckhohn, C. (1952) Culture. A Critical Review of the Concepts and Definitions, Papers of Peabody Museum of Archeology and Ethnography

London: Institute for Cultural Policy Studies.

MARIBOR 2012 - The European Capital of Culture Retrieved from http://www.maribor2012.info/wp-content/uploads/2015/04/From-Challenges-toResults.pdf

Mateja, S. H., David, B., \& Primoz, P. (2015). Sustainable Heritage Management: Social, Economic and Other Potentials of Culture in Local Development. Procedia - Social and Behavioral Sciences 188, 103-110.

Mccarthy, K., Ondjatee, E., Zakaras, L., \& Brooks, A. (2004). Gifts of the muse: Reframing the debate about the benefits of arts, rand research division. Santa Monica: California

Report from the Commission to the European Parliament, the Council, the European Economic and Social Committee and the Committee of the Regions, Brussels, 2013

Rius-Ulldemolins, J. (2014). Culture and authenticity in urban regeneration processes: Place branding in central Barcelona. Urban Studies 51, 3026-3045

Rusu-Tanasa, M. (2015). Economic Prospects in the Context of Growing Global and Regional Interdependencies", IECS 2015 Intellectual Capital a Strategic Factor of SocioEconomic Development of Regions and Countries. Procedia Economics and Finance 27, pp. $369-374$.

Ságvári, B., \& Dessewffy, T. (2006). A kreativ gazdaságról - Európa és Magyarország a kreativ korban. Demos Magyarország, Budapest.

Tallinn Annual Report 2011, Tallinn City Office

Torre, A., \& Scarborough, H. (2017). Reconsidering the estimation of the economic impact of cultural tourism. Tourism Management 59 (April 2017), 621-629

Tourism in Tallinn 2011; Tallinn City Tourist Office \& Convention Bureau, 2012 Retrieved from https:/www.muurileht.ee/en/the-rooftop-cinemas-5th-season-is-about-to-start/

Tudorache, P. (2016). The importance of the intangible cultural heritage in the economy. Procedia Economics and Finance 39, 731 - 736

Williams, R. (2003). Kultúra. In: Wessely, A. (szerk.): A kultúra szociológiája. OsirisLáthatatlan Kollégium, Budapest, pp. 28-32.

www.uneecc.org 